\title{
Diversely moving towards a green economy: Techno-organisational decarbonisation trajectories and environmental policy in EU sectors
}

\author{
Massimiliano Mazzanti *, Ugo Rizzo \\ Department of Economics and Management, University of Ferrara, Ferrara, E SEEDS (www.sustainability-seeds.org) Italy
}

\section{A R T I C L E I N F O}

\section{Article history:}

Received 13 May 2014

Received in revised form 12 September 2016

Accepted 23 September 2016

Available online $\mathrm{xxxx}$

\section{JEL classification:}

L52

033

Q58

\section{Keywords:}

Techno-organisational change

Climate change

EU 20302050 targets

Sectors

Eco-innovations

Climate policy

Energy policy

\begin{abstract}
A B S T R A C T
This paper adopts an ex ante perspective to investigate the potential techno-organisational dynamics related to reducing greenhouse gas (GHG) emissions in the EU by 2030 and 2050 . We provide a qualitative analysis based on interviews with representatives from the main manufacturing sectors in the EU. Path dependency and enhanced carbon pricing may support the 'incremental path'. More radical changes are achievable through strong techno-organisational reorganisation and new policy support. It follows that technological innovation is sufficiently effective only if coupled with organisational innovation. Earmarking 'environmental revenues' to support sector R\&D is a way to enhance the governance of the innovation-policy realm and create opportunities for radical innovation.
\end{abstract}

(c) 2016 Published by Elsevier Inc.

\section{Introduction}

In October 2014, the European Council set a new climate change mitigation target of a $40 \%$ cut in greenhouse gas (GHG) emissions for 2030 with respect to 1990 levels (EUCO, 2014). This adds to the already binding $20 \%$ cut to be reached by 2020 and has the purpose of helping the EU meet the more stringent goals proposed for 2050. The EU also led the way in the effort to conclude the "first-ever universal, legally binding global climate deal" that established a $1.5^{\circ} \mathrm{C}$ threshold increase in global temperatures (Paris Agreement COP21). The challenge is to combine competitiveness with decarbonisation to meet these targets (Fankhauser et al., 2008).

The path to decarbonisation needs to be characterised by a portfolio of actions in which innovation compensates for the economy-scale effects on emissions, namely, GDP and population growth (EEA, 2014). Consequently, changes to the energy mix, greater energy efficiency and other incremental and radical solutions are required (McGlade and Ekins, 2015). Furthermore, technological, organisational and behavioural innovations are increasingly important (Costantini and Mazzanti,

\footnotetext{
* Corresponding author at: Department of Economics and Management, University of Ferrara, via Voltapaletto 11, 44121 Ferrara, Italy.

E-mail address: massimiliano.mazzanti@unife.it (M. Mazzanti).
}

2013; van den Bergh, 2007; Edenhofer et al., 2012), and environmental innovations, or eco-innovation (EI), ${ }^{1}$ represent a crucial component of techno-organisational change (Jaffe et al., 1995).

The 2020 EU target (a 20\% reduction in emissions) seems to be achievable, but this is partly due to the EU's ongoing scenario of low economic growth, very high unemployment and deflation. This challenge is linked to another issue that tends to be overlooked: the (non-binding) EU strategy established in 2012 to move from a $16 \%$ share of manufacturing to 20\% (of GDP) by 2020 (EC, 2010). This in turn suggests that environmental and economic targets should be integrated. In the short term, re-manufacturing might increase direct emissions, but at the same time, manufacturing is more (eco-) innovative than services (Cainelli and Mazzanti, 2013; Gilli et al., 2013).

The 'decarbonisation burden' in fact mostly falls on the industrial and transportation macro-sectors, which are generally more polluting but also more innovative than service sectors (Cainelli and Mazzanti, 2013; Gilli et al., 2013). Moreover, Mazzanti et al. (2015, p.729) show that inter-sector integration and knowledge sources matter and that sectors with more emission-intensive upstream 'partners'

\footnotetext{
${ }^{1}$ For a consolidated definition, see Kemp (2010). The definition includes new organisational methods, products, services and knowledge-oriented innovations (see also Kemp and Pontoglio, 2011).
} 
eco-innovate more to reduce their $\mathrm{CO}_{2}$ footprints. Sector-specific analyses are therefore required for an in-depth investigation of the role of innovation and structural change towards the decarbonisation of the economy (Kettner et al., 2015).

Sector dynamics are attracting increased interest in environmental research, which has mostly been driven by the integration of evolutionary and environmental economics (see, e.g., Borghesi et al., 2013; van den Bergh, 2007). However, the existing studies (e.g., Marin and Mazzanti, 2013) tend to neglect "the interdependencies between environmental innovations and the industrial dynamics of sectors" (Oltra and Saint Jean, 2009, p. 579).

This work seeks to provide an in-depth investigation of three of the main polluting sectors in the EU. Based on interviews with sector experts (Borghesi et al., 2015a; Carrillo-Hermosilla et al., 2010; Baker et al., 2014), we adopt a qualitative ex-ante approach to the issue at hand that complements (i) the quantitatively oriented literature that assesses the drivers of innovation ex-post (Horbach et al., 2012; Borghesi et al., 2015b, among others) and (ii) work on macro modelling, such as integrated assessment models (McGlade and Ekins, 2015), GTAP-energy models (Antimiani et al., 2013), and agent-based models (Monasterolo et al., 2014). These studies, which are based on plausible assumptions about the endogenisation of technological change and innovation (Costantini and Mazzanti, 2013; Durance and Godet, 2010; Rosen and Guenther, 2015), are aimed at generating medium/ long-term scenarios for GDP, $\mathrm{CO}_{2}$ and other variables of interest. Conversely, as Carrillo-Hermosilla et al. (2010) note, "case studies are able to capture the details of eco-innovations, which are unnoticed in top-down aggregate quantitative analysis" (p.1078). Moreover, "sectors provide a key level of analysis for economists in the examination of innovative and productive activities, [for which] case studies provide a rich (and heterogeneous) set of empirical evidence" (Oltra and Saint Jean, 2009, p. 567).

Our research questions are related to the extent to which both policy and market factors induce environmental innovations ${ }^{2}$ aimed at reaching GHG reduction targets for 2030 and 2050 . We focus on both technological and organisational innovations - incremental and radical - (Carrillo-Hermosilla et al., 2010) and on the links among different innovations. As in the work by Oltra and Saint Jean (2009), we are interested in the ex-ante assessment of the drivers of EI at the sectoral level. Patterns of sectoral innovation develop as the result of the interplay between "technological regimes, market demand conditions and environmental and innovation policy" (Oltra and Saint Jean, 2009, p.572), and environmental policies are scrutinised through a political economy lens (Pearce, 2006). We also rely heavily on ideas of dynamic efficiency in policies and the governance dimension of EI (Carrillo-Hermosilla et al., 2010).

\section{Eco-innovation, sectoral specificities, and environmental policies}

The evidence highlights some key points about the role of innovation in moving towards a green economy. First, incremental innovation adoption has primarily characterised the dynamics of EI in the EU (Horbach et al., 2012; Cainelli et al., 2011), which indicates some heterogeneity across sectors (Borghesi et al., 2015a, 2015b). Incremental innovations prompted the trend towards the achievement of 2020 targets. However, radical innovations are necessary with respect to 2050 targets. This requires assessing both the economic feasibility of a blockbuster, i.e., very costly technologies such as carbon capture and storage (CCS), and the enhancement of complementary technological and organisational innovations. These radical changes are related to the structural development of human capital/skills (Carraro et al., 2014; Vona et al., 2015) and may represent a more feasible route to effective and innovation-intense climate strategies, even in the short and

\footnotetext{
${ }^{2}$ For a comprehensive analysis and taxonomy of EI, we mainly refer to Carrillo-
} Hermosilla et al. (2010) and Huppes et al. (2008). medium term (Wagner, 2013; Antonioli et al., 2013). Complementarity in innovation is a radical asset that can strongly enhance performance through innovation and the redesign of corporate strategies (Mohnen and Roller, 2005; Ambec et al., 2013).

Some authors refer to the transition towards the long-term climate change targets as the '6th technological revolution', an 'age of a low carbon - resource efficient economy' (Grubb, 2014; Perez, 2009). The low carbon economy has the potential to open "a vast innovation opportunity space and [provide] a new set of associated generic technologies, infrastructures and organisational principles that can significantly increase the efficiency and effectiveness of all industries and activities" (Perez, 2009, p. 6).

The diffusion of innovation is crucial; therefore, it is important to understand how innovations are idiosyncratically and jointly adopted by firms in different sectors and subsequently spread through sectors. Sectoral issues are of considerable interest in the literature on the economics of innovation (Malerba and Orsenigo, 1997) and, more recently, environmental economics (Jaffe et al., 1995; Crespi, 2013; Costantini and Mazzanti, 2012).

Various studies have increased our understanding of the interconnections among firms in different sectors. Castellacci (2008) argues that manufacturing and services are deeply interconnected and that knowledge exchange across different industries is the source of national competitive advantage. The author also maintains that this knowledge exchange positively affects the technological development of more traditional industries. Similarly, Consoli and Rentocchini (2014) draw on the composition of skills in different industrial sectors to illustrate how industrial organisation relies on the knowledge base of a firm and the interactions among the knowledge bases of others.

Heterogeneity among sectors must also not be neglected in the context of environmental policy. The relatively higher efficiency of carbon taxes (economic instruments in general) with respect to command and control regulation (e.g., technology standards) largely relies on the differences in marginal emission abatement costs across firms: a tax brings about different abatements across agents and consequently enhances greater efficiency and social welfare than a command and control tool (e.g., Stiglitz, 2015). Even outside a strictly 'optimal' Pigouvian design, a price signal minimises pollution abatement costs through its static and dynamic efficiency properties (Fig. 1), and it does this regardless of market structure. We can exploit environmental policies focusing on 'efficiency without optimality' (Baumol and Oates, 1988). Cost minimisation and the ongoing incentives to innovate are key tools through which environmental taxes and other economic instruments may better operate in a context of heterogeneous agents in which both economics and political economy arguments are relevant (Pearce, 2006).

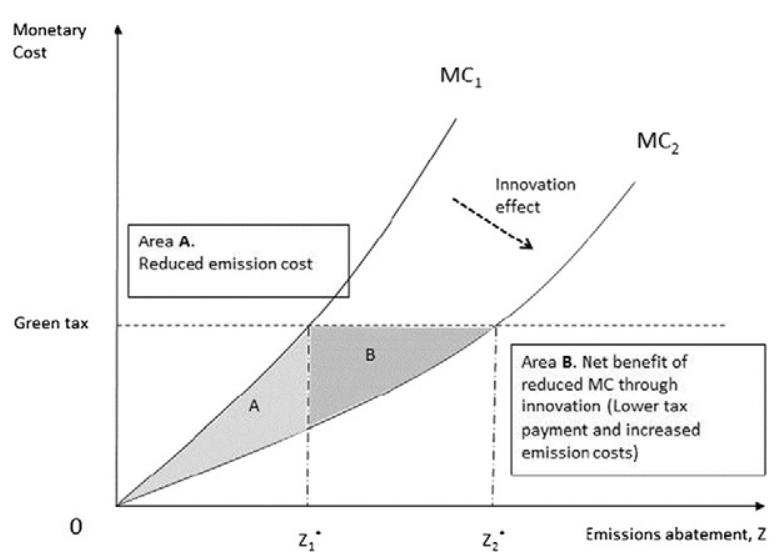

Fig. 1. Dynamic innovation effects of a tax on the environment. 
After many years of discussing the implementation of fiscally neutral ecological tax reforms (since the Delors Commission white book, with only Northern EU countries introducing some of those policies), the EU suddenly opted for the other key economic instrument: emission trading. The EU emission trading system (ETS) was implemented in 2005 (following the EU 2003 Directive) and became the key EU climate policy tool (Borghesi et al., 2016).

Although both economic instruments (taxes and tradable permits) can deliver static and dynamic incentive mechanisms, carbon taxes may better support sector-specific investments if economic players suffer the price-uncertainty associated with ETS 'financial' carbon prices (Borghesi et al., 2016). Taxes set the price and leave quantity free, but the opposite occurs with trading: quantities are given (emission targets and quotas), and prices float in the market (the so-called price versus quantity issue). Political economy issues are also relevant to judge a policy design, namely, how those policies are implemented and how eventual revenues are allocated.

In the first phase of the EU ETS, there was a typical free allocation of allowances, and sectors faced different restrictions depending on the emissions/allowances ratio. Given that the initial allocation of allowances is subject to some 'political' burden-sharing and path dependency (historical emissions accounting), different sectors received different, mixed and temporally changing signals (Borghesi et al., 2015b).

It is worth noting that the alternative auctions-based ETS, to which the EU system will converge through a transition, has two outcomes: it directly reveals the willingness-to-pay for $\mathrm{CO}_{2}$ abatement by firms and generates fiscal revenues from taxes (Ekins and Speck, 2011). Revenues may allow for the recycling of resources back into sectors and eventually earmarking funds for specific green innovations. The new auction phase of the EU ETS, in addition to complementing existing energy/carbon taxes, may shape policies according to sectoral and regional features by following a more bottom-up and diversified approach (Epicoco et al., 2014). Climate, innovation and industrial policies are thus thought to be conceptually integrated.

If carbon pricing, whether through taxes or permits or eventually mixed schemes, would exert dynamic efficiency effects, then innovation funding could be tailored to necessities, and the choice would be whether to fund general R\&D, specific innovations, innovation integration, overall environmental efficiency goals, etc. In other words, carbon pricing and innovation funding might cope with the issue of sector/firm heterogeneity in a complementary way. These insights are often overlooked in the formulation of policies that target specific sectors. Sectors represent a crucial and unique 'space' where innovation is developed and diffused (Peneder, 2010, p. 324).

\section{Research design}

This work explores the future medium-long-term dynamics in relation to sector-specific abatement strategies. A complementary exercise to modelling techniques, which are widely used to inform policy makers about uncertain future events, especially in the realm of climate change, is to gather expert opinions (Arnell et al., 2005; Nordhaus, 1994; Morgan and Keith, 1995; Zubaryeva et al., 2012; Varho and Tapio, 2013; Räthze and Uzzell, 2011). Our analysis is focused on three industries which are widely affected by the EU ETS: ceramics, energy, and steel. Those sectors bring about a relatively large impact in terms of direct $\mathrm{CO}_{2}$ emissions (Marin and Mazzanti, 2013; EEA, 2014 and Fig. 2). These three sectors are all classified as heavy industry and are highly regulated.

We identified 53 industrial associations across Europe along with associated experts linked to the sectors under consideration. Associations were identified within and through the EU FP7 Project Cecilia2050 (www.cecilia2050). A questionnaire was developed to address experts and elicit original information. We contacted the associations related to the identified sectors and invited their technical directors to participate in a study on techno-organisational innovation patterns and strategies related to the GHG 2030 and 2050 EU reduction targets. Industrial associations were first contacted by email and then followed up with non-responses by phone. ${ }^{3}$ It was possible to interact with 30 associations and thereby obtain responses from 11 experts from 10 different associations. In most of the cases, the respondent/interviewee was the technical director of the association. To provide a more comprehensive picture of possible future scenarios (Keith, 1996) and to enable data triangulation (Jick, 1979; Yin, 2008), we also interviewed academic experts and the technical directors of some multinational companies that are leaders in their particular sectors (cf. also Borghesi et al., 2015a).

Experts could decide to interact between a telephone interview and an online questionnaire. To clarify the basis and objectives of the analysis, the questionnaire began with a definition of EI (Kemp, 2010). The questions concerned which innovations, technological and organisational, should be developed to reduce GHG emissions in the EU by 2030 and by 2050, and both market and policy factors were considered as drivers of the changes needed to achieve the expectations of the EU strategy.

The questionnaire was semi-structured, and half of the questions were open-ended to avoid imposing constraints on the respondents (Bostrom et al., 1994; Read et al., 1994). Rather than collect data and elicit information to formalise and quantify probability distributions for a number of different scenarios (e.g., Morgan and Keith, 1995; Keith, 1996), we decided to collect the opinions of a set of experts to formulate policy implications (Keith, 1996; Arnell et al., 2005; Baker et al., 2014).

Ultimately, 27 European experts were involved. ${ }^{4}$ Telephone interviews lasted $45 \mathrm{~min}$ on average and included 'follow-up' questions when necessary to gain a more detailed understanding of critical issues. Details are provided in Table 1 . The information was integrated with an analysis of the literature and other reports.

\section{Discussion: Technological trajectories towards the 2030 and 2050 climate targets in three EU industry sectors}

Detailed sector analyses are provided in the supplementary material section. The results for the three sectors are summarised in Table 2. The analysis reveals considerable differences among sectors and some important commonalities among strategies and perspectives.

The overall message is that both radical and incremental innovations will be needed if the EU GHG reduction targets are to be met, but radical technologies will be essential to approximate the EU targets (Jänicke and Lindemann, 2010). The analysis of sector specificities highlights the insufficiency of technological development alone; more specifically, the evidence highlights the need to couple market- and regulationdriven technological policy pushes with other measures. These other measures include the imposition of regulations or the development of specific quotas, such as renewable quotas, and the generation and adoption of organisational innovations, which mainly refer to the need to create a common and decentralised market and improve citizen behaviours. This was mentioned across sectors. The analysis of the interview materials shows that technical issues and innovation are just one side of the coin: technological innovation will only have an impact if coupled with organisational and societal innovations.

Two important differences across sectors are the following: (i) Incremental technologies emerge as a very important and potentially sufficient determinant for achieving the 2030 targets in the energy sector but not the steel or ceramics sectors. (ii) Radical innovation was considered necessary for the steel industry and was barely mentioned in relation to the ceramics sector. In fact, the ceramics sector is

\footnotetext{
3 The list of associations is provided in the supplementary material section.

4 The experts interviewed represent the different countries as follow: Italy (15), the Netherlands (2), Spain (2), Belgium (1), Germany (2), Poland (2), the UK (2), and International bodies (1).
} 

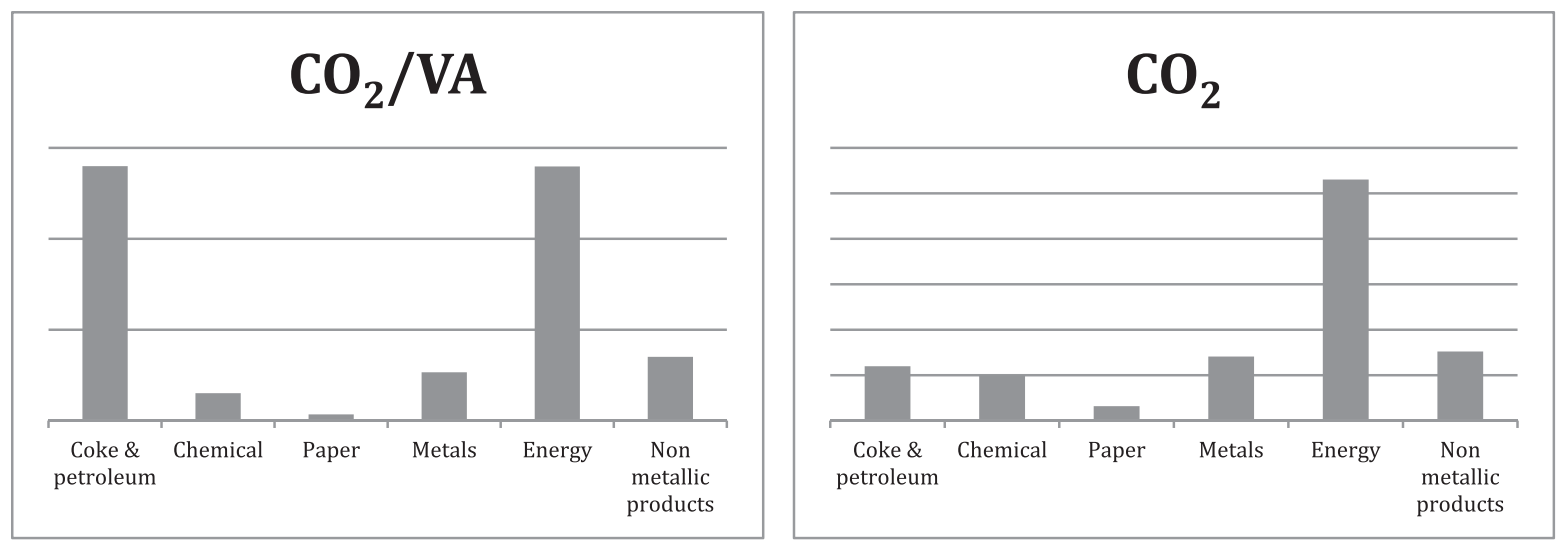

Fig. 2. $\mathrm{CO}_{2} / \mathrm{VA}$ and $\mathrm{CO}_{2}$ emissions in EU27 by sector, 2009.

Source: authors' elaboration on WIOD (www.wiod.org) data (Y axes: Ratio between $\mathrm{CO}_{2}$ and value added, and tons of $\mathrm{CO}_{2}$, respectively).

exhibiting a delayed response to the climate challenge, perhaps explained by the smaller size of ceramics firms, a critical phase in the economic cycle, and the wave of green investments that occurred in the late 1990s.

This paper highlights the need for some sectors, such as ceramics and steel, to be specifically considered in relation to their strategic role in the European economy. Ceramics and steel should be evaluated based on the complementarities between these and other sectors, especially downstream; improving the quality of materials could enhance energy savings across a wide variety of economic production processes.

The investigation demonstrates the need to complement ex ante with ex post analyses and qualitative with quantitative studies, especially in the complex realm of innovation dynamics. The results of econometric analysis and scenario definition using macroeconomic models are enriched by qualitative ex ante examinations.

\section{Conclusions}

European industry is currently operating between the first and second phases of the technological revolution identified by Grubb (2014). The first phase involves reaping the benefits of win-win energy strategies, which are similar to business-as-usual options but are supported by more social and scientific awareness and new policy commitment. The second phase involves the optimisation of strategies based on incremental evolution in response to current or anticipated prices for high carbon/low carbon uses. Transformations through the integration of energy and economic and environmental systems are in their infancy (third phase), although some strategies (e.g., innovation synergies/complementarity) represent a move in that direction. We are thus in the earliest phase of a new technoeconomic paradigm, which is "the result of a complex collective learning process" (Perez, 2009, p. 14).

The current challenge at the EU level is the $40 \%$ cut in emissions, which is a pre-condition for achieving the $2{ }^{\circ} \mathrm{C}$ stabilisation by approximately 2050. The 2015 COP21 in Paris generated a consensus on the stabilisation target: regions, countries and continents must now find effective solutions in the absence of a global government. The EU is a key example of a leading area whose industries should nevertheless respond to internationally coherent and economically efficient policies. Nevertheless, an increasingly stringent and credible policy seems necessary, even when considering the current sluggishness of the oil market. Ecological tax reforms (ETR) (within a new energy-climate policy package) and the new auction-based phase of the EU ETS offer a way to earmark resources to sectors to sustain the low carbon technological revolution that, perhaps more than in the case of past revolutions, must have a clear and robust policy message
(Mazzucato, 2013). If the objective is to develop breakthrough technologies in the relatively short term, large and deliberate investments in R\&D will be needed, and, while carbon pricing provides an initial and general stimulus for incremental sectoral innovations, radical innovations require policies directed at the environment and innovation. ETR and ETS might provide sufficient R\&D incentives and funding to enable sectors to face the 'double externality problem' and manage the 'variation in requirements imposed on different sectors' (Oltra and Saint Jean, 2009).

Thus, policy should account for the characteristics of different sectors in terms of innovation diffusion and integration. This work has highlighted the need for a broad and integrated inter-sectoral approach to analysing sectoral economic and environmental performance, an approach that encompasses manufacturing and considers the linkages between services and manufacturing. A main element that emerged through this analysis and that has been neglected in the policy realm is the ' $\mathrm{CO}_{2}$ mitigation enabler' role of heavy polluting sectors such as ceramics and steels: the use of innovative products developed in these sectors affects the resource and energy efficiency of a wide range of goods. These considerations and their integration in the policy design governance seem particularly important to determining how the 2050 GHG reduction target can be met, especially with respect to the intention to increase the share of manufacturing in the EU.

\section{Acknowledgements}

The article is based on work carried out in the following research project: 'Climate changes in the Mediterranean area: scenarios, mitigation policies and technological innovation' funded by the National Research Project PRIN-MIUR 2010-11, and the 'CECILIA2050' research project, funded by the European Union under the 7 th Framework Programme for Research (grant agreement $n^{\circ} 308680$, www.cecilia2050.eu).

Table 1

The set of interviewed experts.

\begin{tabular}{|c|c|c|c|}
\hline & Energy & Ceramics & Steel \\
\hline \multicolumn{4}{|l|}{ Interview type } \\
\hline Direct interview & 3 & 4 & 5 \\
\hline Online & 7 & 3 & 5 \\
\hline \multicolumn{4}{|c|}{ Affiliation of respondents } \\
\hline Sectoral associations & 5 & 2 & 4 \\
\hline Academia & 3 & 1 & 1 \\
\hline Companies & 2 & 4 & 5 \\
\hline
\end{tabular}


Table 2

Innovations and actions identified by experts to meet the GHG reduction target.

\begin{tabular}{|c|c|c|c|c|c|}
\hline \multirow[t]{2}{*}{ Sector } & \multirow{2}{*}{$\begin{array}{l}\text { Sector-specific current state } \\
\text { in face of future targets }\end{array}$} & \multicolumn{2}{|l|}{2030} & \multicolumn{2}{|l|}{2050} \\
\hline & & $\begin{array}{l}\text { Most prominent Innovation } \\
\text { strategies }\end{array}$ & $\begin{array}{l}\text { Relevant policy and market } \\
\text { issues }\end{array}$ & $\begin{array}{l}\text { Most prominent Innovation } \\
\text { strategies }\end{array}$ & $\begin{array}{l}\text { Relevant policy and market } \\
\text { issues }\end{array}$ \\
\hline Energy & $\begin{array}{l}\text { Europe could reach } 80 \% \text { of } \\
\text { the GHG reduction target by } \\
2050 \text { by only developing } \\
\text { technology already available } \\
\text { today. Energy sector is } \\
\text { largely connected to other } \\
\text { sectors (e.g., building). }\end{array}$ & $\begin{array}{l}\text { Technological incremental: } \\
\text { energy efficiency, } \\
\text { renewables. Organisational: } \\
\text { decentralisation of energy } \\
\text { generation, involvement of } \\
\text { citizens. }\end{array}$ & $\begin{array}{l}\text { R\&D and Innovation subsidies. } \\
\text { Definition of standards. RES } \\
\text { policies. Oil and carbon price: } \\
\text { positive effect on adoption of } \\
\text { renewables. Behavioural } \\
\text { incentives to citizens and } \\
\text { workers }\end{array}$ & $\begin{array}{l}\text { Radical: energy storage, CCS. } \\
\text { Organisational: involvement } \\
\text { of citizens }\end{array}$ & $\begin{array}{l}\text { Definition of standards, } \\
\text { common market, smart grid } \\
\text { infrastructure. Public } \\
\text { investment. Oil and carbon } \\
\text { price. Behavioural incentives } \\
\text { to citizens and workers }\end{array}$ \\
\hline Steel & $\begin{array}{l}\text { Steel production based on } \\
\text { two main cycles: BF-BOF and } \\
\text { Scrap-EAF, where the first } \\
\text { leads to higher level } \\
\text { products but higher } \mathrm{CO} 2 \\
\text { emission and is responsible } \\
\text { for } 59 \% \text { of } 2010 \text { EU steel } \\
\text { production. Recent decrease } \\
\text { in } \mathrm{CO}_{2} \text { emissions mostly due } \\
\text { to decrease in production. } \\
\text { Largely dependent on } \\
\text { energy. Largely connected to } \\
\text { other production (e.g., car } \\
\text { industry) }\end{array}$ & $\begin{array}{l}\text { Technological incremental: } \\
\text { shift towards scrap-EAF, } \\
\text { electricity sourced by } \\
\text { renewables. }\end{array}$ & $\begin{array}{l}\text { Limit energy price volatility. } \\
\text { Subsidise R\&D and } \\
\text { innovation adoption. Create } \\
\text { a competitive market. } \\
\text { Definition of standards. Oil } \\
\text { and carbon price: negative } \\
\text { effect on delocalisation of } \\
\text { production. }\end{array}$ & Radical: CCS & $\begin{array}{l}\text { Limit energy price volatility. } \\
\text { Create a competitive market. } \\
\text { Consider role of steel as } \\
\text { mitigation enabler. }\end{array}$ \\
\hline Ceramics & $\begin{array}{l}\text { Recent decrease in } \mathrm{CO}_{2} \\
\text { emissions is mostly due to } \\
\text { decrease in production. EU } \\
\text { ceramics industry accounts } \\
\text { for almost } 25 \% \text { of global } \\
\text { production. Largely } \\
\text { connected to a wide variety } \\
\text { of other industrial } \\
\text { production }\end{array}$ & $\begin{array}{l}\text { Technological incremental: } \\
\text { energy savings, } \\
\text { cogeneration, electrification } \\
\text { of kilns, electricity sourced } \\
\text { by renewables. } \\
\text { Organisational: green } \\
\text { demand as driver. }\end{array}$ & $\begin{array}{l}\text { Subsidise R\&D and } \\
\text { innovation adoption. } \\
\text { Definition of standards. Oil } \\
\text { and carbon price: marginally } \\
\text { relevant. }\end{array}$ & - & $\begin{array}{l}\text { Consider role of ceramics as } \\
\text { mitigation enabler. Smart } \\
\text { grid infrastructure. }\end{array}$ \\
\hline
\end{tabular}

\section{Appendix A. Supplementary data}

Supplementary data to this article can be found online at http://dx. doi.org/10.1016/j.techfore.2016.09.026.

\section{References}

Ambec, S., Cohen, M.A., Elgie, S., Lanoie, P., 2013. The Porter Hypothesis at 20: can environmental regulation enhance innovation and competitiveness? Rev. Environ. Econ. Policy 7 (1), 2-22.

Antimiani, A., Costantini, V., Martini, C., Salvatici, L., Tommasino, M.C., 2013. Assessing alternative solutions to carbon leakage. Energy Econ. 36, 299-311.

Antonioli, D., Mancinelli, S., Mazzanti, M., 2013. Is environmental innovation embedded within high-performance organisational changes? The role of human resource management and complementarity in green business strategies. Res. Policy (May).

Arnell, N.W., Tompkins, E.L., Adger, W.N., 2005. Eliciting information from experts on the likelihood of rapid climate change. Risk Anal. 25, 1419-1431.

Baker, E., Bosetti, V., Jenni, K.E., Ricci, E.C., 2014. Facing the experts: survey mode and expert elicitation. Nota di Lavoro 1.2014. Fondazione Eni Enrico Mattei.

Baumol, W., Oates, W., 1988. The Theory of Environmental Policy. 2nd edition. Cambridge University Press, New York, p. 1988.

Borghesi, S., Costantini, V., Crespi, F., Mazzanti, M., 2013. Environmental innovation and socio-economic dynamics in institutional and policy contexts. J. Evol. Econ. 23 (2), 241-245.

Borghesi, S., Crespi, F., D'Amato, A., Mazzanti, M., Silvestri, F., 2015a. Carbon abatement, sector heterogeneity and policy responses: evidence on induced eco innovations in the EU. Environ. Sci. Pol. 54, 377-388.

Borghesi, S., Cainelli, G., Mazzanti, M., 2015b. Linking emission trading to environmental innovation: Evidence from the Italian manufacturing industry. Res. Policy 44 (3), 669-683.

Borghesi, S., Montini, M., Barreca, A., 2016. The European Emission Trading System and its Followers. Springer.

Bostrom, A., Morgan, M.G., Fischhoff, B., Read, D., 1994. What do people know about global climate change? 1. Mental Models. Risk Anal. 14, 959-970.

Cainelli, G., Mazzanti, M., Zoboli, R., 2011. Environmental innovations, complementarity and global/local factors. Int. J. Technol. Policy Manage 11, 328-368.

Cainelli, G., Mazzanti, M., 2013. Environmental innovations in services: Manufacturingservices integration and policy transmissions. Res. Policy 42 (9), 1595-1604.

Carraro, C., De Cian, E., Tavoni, M., 2014. Human capital, innovation and climate policy: an integrated assessment. Environ. Model. Assess. 19, 85-98.

Carrillo-Hermosilla, J., Del Río, P., Könnölä, T., 2010. Diversity of eco-innovations: reflections from selected case studies. J. Clean. Prod. 18 (10), 1073-1083.
Castellacci, F., 2008. Technological paradigms, regimes and trajectories: manufacturing and service industries in a new taxonomy of sectoral patterns of innovation. Res. Policy 37, 978-994.

Consoli, D., Rentocchini, F., 2014. A taxonomy of multi-industry labour force skills. Res. Policy (forthcoming).

Costantini, V., Mazzanti, M., 2012. On the green side of trade competitiveness? Res. Policy 41, 1-32 (February)

Costantini, V., Mazzanti, M., 2013. The dynamics of economic and environmental systems. Innovation, Policy and Competitiveness. Springer.

Crespi, F., 2013. Environmental policy and induced technological change in EU industries 2013 In: Costantini, V., Mazzanti, M. (Eds.), The Dynamics of Economic and Environmental Systems. Innovation, Policy and Competitiveness. Springer.

Durance, P., Godet, M., 2010. Scenario building: uses and abuses. Technol. Forecast. Soc Chang. 77 (9), 1488-1492.

EC, 2010. Communication from the Commission to the European Parliament, the Council, the European and Social Committee and the Committee of the regions. An Integrated Industrial Policy for the Globalisation EraPutting Competitiveness and Sustainability at Centre Stage 2010. COM, Brussels, p. 614 (Available at: http://ec.europa.eu).

Edenhofer, O., Carraro, C., Hourcade, J.-C., 2012. On the economics of decarbonization in an imperfect world. Clim. Chang. 114 (1), 1-8.

EEA, 2014. Resource Efficient Green Economy and EU Policies. EEA, Copenhagen.

Ekins, P., Speck, S., 2011. Environmental Tax Reform (ETR). A Policy for Green Growth. Oxford University Press.

Epicoco, M., Oltra, V., Saint Jean, M., 2014. Knowledge dynamics and sources of eco-innovation: mapping the green chemistry community. Technol. Forecast. Soc. Chang. 81, 388-402.

EUCO, 2014. European Council (23 and 24 October 2014), Conclusions. EUCO 169/14

Fankhauser, S., Sehlleier, F., Stern, N., 2008. Climate change, innovation and jobs. Clim. Pol. 421-429.

Gilli, M., Mazzanti, M., Nicolli, F., 2013. Sustainability, environmental innovations and competitiveness in evolutionary perspectives. Evidence from the EU. J. Socio-Econ. (June)

Grubb, M., 2014. Planetary Economics. Routledge.

Horbach, J., Rammer, C., Rennings, K., 2012. Determinants of eco-innovations by type of environmental impact-the role of regulatory push/pull, technology push and market pull. Ecol. Econ. 78, 112-122.

Huppes, G., Kleijn, R., Huele, R., Ekins, P., Shaw, B., Esders, B., Schaltegger, S., 2008 Measuring eco-innovation: framework and typology of indicators based on causal chains. Final Report of the ECODRIVE Project. CML, Leiden.

Jaffe, A.B., Peterson, S.R., Portney, P.R., Stavins, R.N., 1995. Environmental regulation and the competitiveness of US manufacturing: what does the evidence tell us? J. Econ. Lit. 132-163.

Jänicke, M., Lindemann, S., 2010. Governing environmental innovations. Environ. Polit. 19, 127-141. 
Jick, T.D., 1979. Mixing qualitative and quantitative methods: triangulation in action. Adm. Sci. Q. 24, 602-611.

Keith, D.W., 1996. When is it appropriate to combine expert judgments? An editorial essay. Clim. Chang. 33, 139-143.

Kemp, R., 2010. Eco-innovation: definition, measurement and open research issues. Econ. Polit. J. Inst. Econ. 3, 397-420.

Kemp, R., Pontoglio, S., 2011. The innovation effects of environmental policy instruments-a typical case of the blind men and the elephant? Ecol. Econ. 72, 28-36.

Kettner, C., Kletzan-Slamaniga, D., Köppl, A., 2015. The EU Emission Trading Scheme: sectoral allocation and factors determining emission changes. J. Environ. Econ. Policy $4,1-14$.

Malerba, F., Orsenigo, L., 1997. Technological regimes and the firm behaviour. Ind. Corp. Chang. 2 (1), 45-71.

Marin, G., Mazzanti, M., 2013. The evolution of environmental and labour productivity dynamics. J. Evol. Econ. (April).

Mazzanti, M., Marin, G., Mancinelli, S., Nicolli, F., 2015. Carbon dioxide reducing environmental innovations, sector upstream/downstream integration and policy: evidence from the EU. Empirica 42, 709-735.

Mazzucato, M., 2013. The Entrepreneurial State: Debunking Public vs. Private Sector Myths. Anthem.

McGlade, C., Ekins, P., 2015. The geographical distribution of fossil fuels unused when limiting global warming to $2{ }^{\circ} \mathrm{C}$. Nature $517,187-190$.

Mohnen, P., Roller, L.H., 2005. Complementarities in Innovation Policy. Eur. Econ. Rev. 49 (6), 1431-1450.

Monasterolo, I., Jones, A., Tonelli, F., Natalini, D., 2014. A hybrid system dynamics - agent based model to simulate complex adaptive systems: a new methodological framework for sustainability analysis. Proceedings System Dynamics Society Conference 2014.

Morgan, M.G., Keith, D.W., 1995. Subjective judgments by climate experts. Environ. Policy Anal. 29, 468-476.

Nordhaus, W.D., 1994. Expert opinion on climate change. Am. Sci. 82, 45-51.

Oltra, V., Saint Jean, M., 2009. Sectoral systems of environmental innovation: an application to the French automotive industry. Technol. Forecast. Soc. Chang. 76, 567-583.

Pearce, D., 2006. The political economy of an energy tax. Energy Econ. 28, 149-158.

Peneder, M., 2010. Technological regimes and the variety of innovation behaviour: creating integrated taxonomies of firms and sectors. Res. Policy 39 (3), 323-334.

Perez, C., 2009. Technological revolutions and techno-economic paradigms. Camb. J. Econ. $34,185-202$.

Räthze, N., Uzzell, D., 2011. Trade unions and climate change: the jobs versus environment dilemma. Glob. Environ. Chang. 21, 1215-1223.
Read, D., Bostrom, A., Morgan, M.G., Fischoff, B., Smuts, T., 1994. What do people know about global climate change? 2. Survey studies of educated lay people. Risk Anal. 14 (6), 971-982.

Rosen, R.A., Guenther, E., 2015. The economics of mitigating climate change: what can we know? Technol. Forecast. Soc. Chang. 91, 93-106.

Stiglitz, J.E., 2015. Bridging the gap in the context of the financial crisis Joseph E. Stiglitz. Our Common Future under Climate Change. UNESCO, Paris (July 10 available at http://fr.slideshare.net).

Van den Bergh, J., 2007. Evolutionary thinking in environmental economics. J. Evol. Econ. 17 (5), 521-549 Springer. (October).

Varho, V., Tapio, P., 2013. Combining the qualitative and quantitative with the Q2 scenario technique -the case of transport and climate. Technol. Forecast. Soc. Chang. 80, 611-630.

Vona, F., Marin, G., Consoli, D., Popp, D., 2015. Green Skills, NBER Working Paper 21116. NBER.

Wagner, M., 2013. 'Green' human resource benefits: do they matter as determinants of environmental management system implementation? J. Bus. Ethics 114, 443-456.

Yin, R., 2008. Case Study Research. Design and Method. Fourth edition. SAGE Publications

Zubaryeva, A., Thiel, C., Barbone, E., Mercier, A., 2012. Assessing factors for the identification of potential lead markets for electrified vehicles in Europe: expert opinion elicitation. Technol. Forecast. Soc. Chang. 79, 1622-1637.

Massimiliano Mazzanti (university of Ferrara, massimiliano.mazzanti@unife.it) has worked on applied environmental economics and policy issues such as: sustainable development, environment and trade, climate change policies, environmental innovation, environmental and public policy design and assessment, environmental fiscal reforms, resource taxation, economic valuation of the environment, beyond GDP - green accounting. He graduated at the University of Bologna (Italy) then he continued the education with a Msc in Environmental \& Natural Resources Economics at the Department of Economics, UCL London, and Ph. D. in Economics at the University of Rome Tre. Since 2008 he has been associate professor and lecturer in environmental economics at the University of Ferrara. His main research fields and publications deal with environmental policy, economics of innovation, economic performance and innovation, economic evaluation by stated preference techniques, waste management and policy, climate change and development.

Ugo Rizzo (university of Ferrara, ugo.rizzo@unife.it) is a post-doctoral researcher at the University of Ferrara. He obtained a MSc from the University of Manchester and a PhD from the University of Ferrara. His main research interests regard university-industry relationships, entrepreneurship and industrial dynamics. 